\title{
Pt-Catalysed Intermolecular Hydroamination of Non-Activated Olefins Using a Novel Family of Catalysts: Arbuzov-Type Phosphorus Metal Complexes ${ }^{\dagger}$
}

Mireia Rodriguez-Zubiri, ${ }^{*, 1}$ Stéphane Anguille, ${ }^{a, 2}$ Jean-Jacques Brunet ${ }^{a}$ and Jean-Claude $\operatorname{Daran}^{a}$

${ }^{a}$ CNRS, LCC (Laboratoire de Chimie de Coordination), 205 route de Narbonne, BP 44099, Université de Toulouse, UPS, INPT, F-31077 Toulouse Cedex 4, France

${ }^{1}$ Present address: CNRS, CEISAM, UMR 6230, UFR Sciences et Techniques, Université de Nantes, 2 rue de la Houssinière, BP 92208, 44322 Nantes Cedex 3, France. Fax: +33 25112 5402; Tel: +33 25112 5697; e-mail: mireia.rodriguez@univ-nantes.fr.

2 Present address: UMR CNRS 7313 iSm2, Aix-Marseille Université, Centre Saint Jérôme, service 531, 13397 Marseille Cedex 20, France.

$\dagger$ Supplementary information (SI) available. CCDC 878731 - 878733. For SI and Crystallographic data in CIF or other electronic format see DOI 


\section{ABSTRACT}

The catalytic system $\left\langle\mathrm{PtBr}_{2}(0.3 \mathrm{~mol} \%) / 2 \mathrm{P}(\mathrm{OR})_{3} / 10 n \mathrm{Bu}{ }_{4} \mathrm{PBr}\right\rangle(\mathrm{R}=$ alkyl $)$ discovered recently in our group, allows good to excellent catalytic activities for the intermolecular hydroamination of ethylene and higher $\alpha$-olefins (1-hexene) with aniline type amines to give the expected $N$-ethyl- (1) and $N, N$-diethyl-anilines (2) along with 2-methyl-quinoline (3). A poisoning effect of alkyl and aromatic phosphines has been observed. This effect could be minimized using small amounts of molecular iodide which reacts with phosphorus ligands to form non-coordinating well-described ionic species. Interestingly, beneficial effects of added $\mathrm{P}(\mathrm{OR})_{3}(\mathrm{R}=$ alkyl $)$ have been pointed out and further investigated. In this way, a new potential family of Arbuzov-type phosphorus-metal complexes has been suggested to be responsible for good catalytic activities found when using $\mathrm{P}(\mathrm{OR})_{3}$ alkyl phosphites rather than $\mathrm{PR}_{3}(\mathrm{R}=$ alkyl, aromatic $)$ and $\mathrm{P}(\mathrm{OPh})_{3}$ co-catalysts.

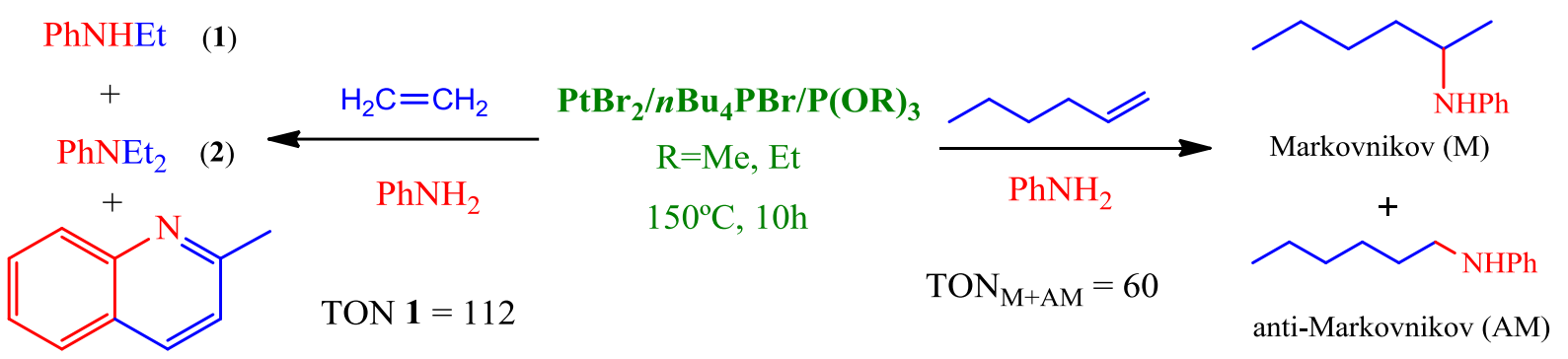

\section{KEYWORDS}

Platinum; phosphorus ligands; Arbuzov; hydroamination; halides. 


\section{INTRODUCTION}

Catalytic hydroamination of alkenes is a practical, economical and sustainable alternative for the preparation of amines and its derivatives. This atom-economic process allows the addition of an N-H bond over an unsaturated carbon-carbon bond to yield a large variety of alkylated amines, very important chemicals in industry and everyday's chemistry. Intense efforts have been devoted to the study and optimisation of this reaction in the past 30 years [1].

Nowadays, the hydroamination reaction could be classified in three categories: the intramolecular hydroamination of olefins [2], the intermolecular hydroamination of activated olefins and alkynes [3] and, the most challenging, the intermolecular hydroamination of nonactivated olefins [1-4]. The latter has known important improvements with the recently discovered Pt and Rh-based catalytic systems [5].

The Pt-based catalysts have shown to be very efficient systems for the intermolecular hydroamination of ethylene (Scheme 1) and 1-hexene (Scheme 2) affording the Markovnikov product with an unprecedented regioselectivity (95\%).

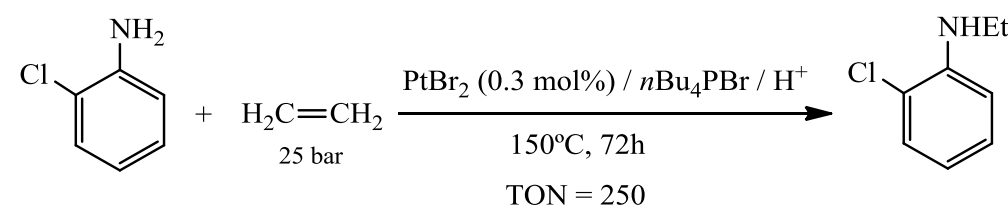

Scheme 1. Intermolecular Pt-catalysed hydroamination of ethylene.

This Pt-based system results from the association of $\mathrm{PtBr}_{2}$ with tetrabutylphosphonium salts.

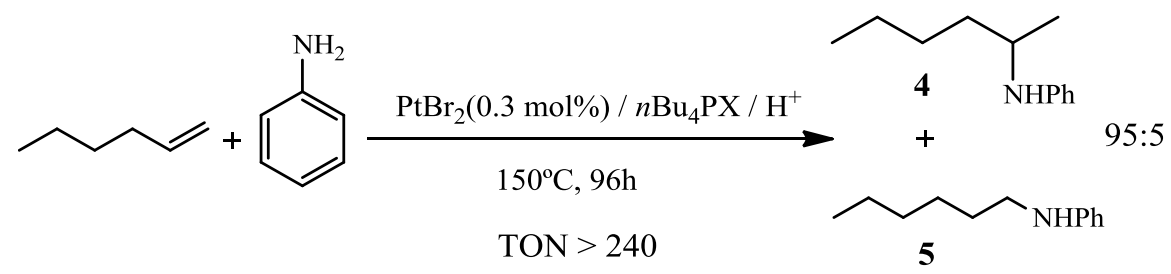

Scheme 2. Intermolecular Pt-catalysed hydroamination of 1-hexene.

It is also noteworthy that this system proved to be as efficient when reactions were performed under aerobic conditions [5b,5c].

The discovery of an original $\mathrm{Rh}^{\mathrm{III}}$-based system, $\mathrm{RhCl}_{3} \cdot 3 \mathrm{H}_{2} \mathrm{O} / 2 \mathrm{PR}_{3} / 65 n \mathrm{Bu}_{4} \mathrm{PI} / 2 \mathrm{I}_{2}$, which consists in the association of simple $\mathrm{Rh}^{\mathrm{III}}$ salts with phosphonium salts and $\mathrm{PR}_{3}$ ligands $\left(\mathrm{PR}_{3}=\right.$ para substituted triarylphosphines, $\mathrm{P}(\mathrm{OMe}) \mathrm{Ph}_{2}$, BINAP, dppe) (Scheme 3) was also described recently [5h]. The latter proved to allow the highest catalytic activity for the intermolecular hydroamination of ethylene, but also 1-butene and 1-hexene, with aniline type amines $(0.3$ mol\% catalytic precursor) to give the expected $N$-ethyl- (1) and $N, N$-diethyl-anilines (2) along with 2-methyl-quinoline (3) (Scheme 3). This system is particularly efficient in the presence of 2,2'-bis(diphenylphosphino)-1,1'-binaphthyl, BINAP $(\mathrm{CE}=460, \mathrm{CE}=$ Catalytic Efficiency $\left.=\mathrm{TON}_{(\mathbf{1})}+2 \mathrm{TON}_{(\mathbf{2})}+2 \mathrm{TON}_{(\mathbf{3})}\right)$ and tri- $(p$-tolyl)phosphine $(\mathrm{CE}=528)$. Good to excellent activities were also found combining the Wilkinson's catalysts ( $\mathrm{Rh}^{\mathrm{I}}$ complexes) with $n \mathrm{Bu}_{4} \mathrm{PI}$ and $\mathrm{I}_{2}$. Interestingly, the simple association of $\mathrm{PPh}_{3}$ and $\mathrm{I}_{2}$ was shown to be an extremely efficient "in situ generated" source of $\mathrm{I}^{-}$promoters able to substitute preformed $n \mathrm{Bu} 4 \mathrm{PI}$. It is important to note that the performance of this Rh-based system depends upon the combination of both $\mathrm{PR}_{3} / \mathrm{I}^{-}$promoters $[5 \mathrm{~g}, 5 \mathrm{~h}]$. 


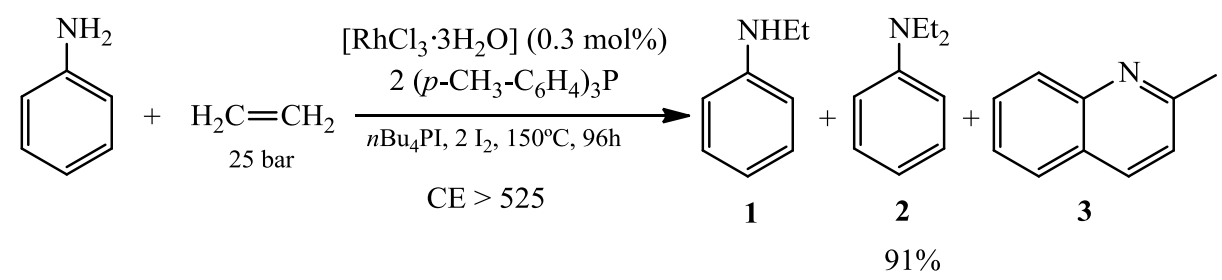

Scheme 3. Rh-catalysed hydroamination of ethylene.

For many years now, the scientific community has brought special attention to the use of phosphorus ligands in catalysis. This vast family of ligands has extensively been reported in the literature as efficient additives for a large amount of homogeneous catalytic processes, including the hydroamination of olefins, offering a valuable source of chirality [6-15].

In this area, the past decade has known an important growth in the use of phosphorus ligands for the intermolecular hydroamination of activated alkenes [6] such as styrenes [7], norbornenes [8], dienes [9], allenes [10], and of alkynes [11], as well as for the intramolecular hydroamination reaction [12-14]. Nevertheless, studies on the association of a catalyst precursor with a phosphine ligand for the intermolecular hydroamination of non-activated alkenes are very scarce [15]. Pioneering this area, Diamond and co-workers explored, for the first time in 1979, the hydroamination of ethylene by aniline using $\mathrm{RhCl}_{3} / 2 \mathrm{PPh}_{3}$ and $\mathrm{PdCl}_{2} / 2 \mathrm{PPh}_{3}$ systems, although low activities were afforded [15d]. After a long silence, in 2001 Keim et al. used a variety of neutral and cationic phosphine and phosphite containing ruthenium complexes to study the hydroamination of ethylene by piperidine achieving good selectivities but low yields [15c]. Interestingly, the hydroamination of 1-hexene combining a copper halide ( $5 \mathrm{~mol} \%)$ and a silver salt $(5-10 \mathrm{~mol} \%)$ in the presence of dppe, reported by Michon and co-workers, allowed up to $90 \%$ yield although branched isomers were formed in a ratio 4/6 [15b]. Recently, Widenhoefer and co-workers successfully hydroaminated 1alkenes with very low basicity amines (cyclic ureas) in the presence of chiral AuClPR ${ }_{3}\left(\mathrm{PR}_{3}=\right.$ $\mathrm{P}(t \mathrm{Bu})_{2} \mathrm{o}$-biphenyl and 2-di-tert-butylphosphino-1,1'-binaphthyl) complexes affording high yields with up to $78 \%$ ee. To the best of our knowledge, this is the only existing report on transition-metal catalysed enantiomeric intermolecular hydroamination of non-activated olefins, showing the urgency to further develop this significant area of broad interest for the scientific community [15a]. The development of stereoselective catalysts for the synthesis of chiral alkylamines could be a useful and practical tool for synthetic chemists and industry, and thus, an important scientific and economic challenge, especially when targeting the intermolecular hydroamination of non-activated olefins.

Herein we report the study on the Pt-catalysed intermolecular hydroamination of ethylene and 1-hexene by aniline in the presence of a variety of phosphorus ligands and a potential explanation on the recovery of the catalytic activity upon the addition of $\mathrm{I}_{2}$. Unexpectedly, the inhibiting effect shown by aryl and alkyl phosphines disappears in the presence of alkyl phosphites. A new potential family of Arbuzov-type phosphorus-metal complexes has been appointed to be responsible for good catalytic activities obtained when using $\mathrm{P}(\mathrm{OR})_{3}$ alkyl phosphites rather than other phosphorus (III) ligands. This study could provide a significant insight on compatible ligands as potential chiral vectors. Furthermore, we have found out an important difference in the coordination behaviour of $\mathrm{PtBr}_{2}$ when reacting with aryl, aryloxy, and alkoxy phosphines leading to a new X-ray structure of a phosphine containing $\mathrm{Pt}^{\mathrm{II}}$ complex. 


\section{EXPERIMENTAL SECTION}

\subsection{Instrumentation}

GC analyses were performed on a Hewlett-Packard HP 4890 (FID) chromatograph (HP 3395 integrator) equipped with a $30 \mathrm{~m}$ HP1 capillary column. GC-MS analyses were performed on a Hewlett-Packard HP 6890 apparatus equipped with a HP 5973 M ion detector. NMR analyses were performed on Bruker AM 250 and 400 machines. $J$ values are given in Hz. Catalytic experiments were conducted in a $100 \mathrm{~mL}$ stainless steel thermoregulated (electric oven) autoclave with a glass liner and a magnetic stirring bar.

\subsection{Methods and Materials}

Potassium bromide (Aldrich, +99\%), 1-iodobutane (Alfa Aesar, 99\%), tri- $n$-butylphosphine (Acros Organics, 95\%), triphenylphosphine (Aldrich, 99\%), triphenylphosphite (Acros, 99\%), trimethylphosphite (Strem, 97\%), methyldiphenylphosphinite (Acros, 99\%), tris((4trifluoromethyl)phenyl)phosphine (Avocado, 98\%), rac-2,2'-bis(diphenylphosphino)-1,1'binaphthyl (Aldrich, 97\%), 1,3-bis(diphenylphosphino)propane (Aldrich, 97\%), 1,10phenantroline (Aldrich, +99\%), potassium tetrachloroplatinate(II) (Aldrich, 98\%) and platinum(II) bromide (Strem Chemicals, 98\%) were used as received. Tetra- $n$ butylphosphonium bromide (Aldrich, 98\%) was stored in a desiccator under vacuum prior to use. Molecular iodine was purchased from Acros Organics.

Aniline (Acros Organics, 99\% for analysis ACS), $N$-ethylaniline (Acros Organics, 98\%), N,Ndi- $n$-butylaniline (Aldrich, 97\%), 1-hexene (Aldrich, 97\%), tri- $t$-butylphosphine (Aldrich, 98\%), trimethylphosphine (Aldrich, 97\%) tris(dimethylamino)phosphine (Aldrich, 97\%) and triethylphosphite (Aldrich, 98\%) were distilled before use and stored under argon. Ethylene $(\mathrm{N} 25,+99.5 \%)$ was purchased from Air Liquide.

Water was deionised and degassed. All other solvents were of HPLC grade and were degassed prior to use.

cis-Dibromobis(trimethylphosphite)platinum(II) [16a a a cisDibromobis(triphenylphosphine)platinum(II) [16b] were prepared according to established methods.

Tetra- $n$-butylphosphonium iodide was prepared from $n \mathrm{Bu}_{3} \mathrm{P}$ and $n \mathrm{BuI}$ (see below), stored under argon, in a freezer, and protected from light.

Tetrabutylphosphonium cis-dibromo(dimethylphosphonato)(trimethylphosphite)platinum(II), 6, was prepared from cis-dibromobis(trimethylphosphite)platinum(II) and tetra- $n$ butylphosphonium bromide (see below).

\subsection{Preparation of tetra(n-butyl)phosphonium iodide}

Tri(n-butyl)phosphine $(38 \mathrm{~mL}, 0.15 \mathrm{~mol})$ was slowly added to 1-iodobutane $(40 \mathrm{~mL}, 0.35$ mol) under argon. The mixture was stirred for $1 \mathrm{~h}$ at RT and then at $100^{\circ} \mathrm{C}$ for $20 \mathrm{~h}$. After cooling, the resulting precipitate was washed with diethylether $(4 \times 50 \mathrm{~mL})$ until a white solid was obtained. Evaporation of residual solvent under vacuum overnight afforded pure $n \mathrm{Bu}_{4} \mathrm{PI}$ as a white powder $(55.6 \mathrm{~g}, 96 \%), \mathrm{mp}=95-96^{\circ} \mathrm{C}$. Anal. Found: C, 49.75; H, 9.57. Calc. for $\mathrm{C}_{16} \mathrm{H}_{36} \mathrm{IP}: \mathrm{C}, 49.74 ; \mathrm{H}, 9.39 . \delta_{\mathrm{H}}\left(250 \mathrm{MHz}\right.$, acetone-d $\left.\mathrm{d}_{6}\right) 0.96\left(3 \mathrm{H}, \mathrm{t},{ }^{3} J 3\right), 1.55(2 \mathrm{H}, \mathrm{m}), 1.70$ $(2 \mathrm{H}, \mathrm{m}), 2.54(2 \mathrm{H}, \mathrm{m}) ; \delta_{\mathrm{P}}\left(250 \mathrm{MHz}\right.$, acetone- $\left.\mathrm{d}_{6}\right) 33.52(\mathrm{~s})$.

\subsection{Preparation of cis- $\left[\mathrm{PtBr}_{2}\left(\mathrm{P}\left(\mathrm{OCH}_{3}\right)_{3}\right)\left(\mathrm{OP}\left(\mathrm{OCH}_{3}\right)_{2}\right)\right]\left(n \mathrm{Bu} \mathrm{u}_{4} \mathrm{P}\right), 6$}

To a vigorously stirred solution of $c i s-\mathrm{PtBr}_{2}\left(\mathrm{P}(\mathrm{OMe})_{3}\right)_{2}(243 \mathrm{mg}, 0.404 \mathrm{mmol})$ in acetonitrile $(2 \mathrm{~mL})$ placed in to a round-bottom flask at $70^{\circ} \mathrm{C}$ (oil bath), was dropwise added another solution of $n \mathrm{Bu}_{4} \mathrm{PBr}(137 \mathrm{mg}, 0.404 \mathrm{mmol})$ in acetonitrile $(2 \mathrm{~mL})$. The reaction mixture was stirred for further $2 \mathrm{~h}$ until completion. Solvent removal afforded cis$\left[\mathrm{PtBr}_{2}\left(\mathrm{P}^{\mathrm{A}}\left(\mathrm{OCH}_{3}\right)_{3}\right)\left(\mathrm{OP}^{\mathrm{B}}\left(\mathrm{OCH}_{3}\right)_{2}\right)\right]\left(n \mathrm{Bu}_{4} \mathrm{P}\right)$ quantitatively $(340 \mathrm{mg})$. Anal. Found: $\mathrm{C}, 29.78 ; \mathrm{H}$, 
6.25. Calc. for $\mathrm{C}_{21} \mathrm{H}_{51} \mathrm{O}_{6} \mathrm{P}_{3} \mathrm{Br}_{2} \mathrm{Pt}: \mathrm{C}, 29.76 ; \mathrm{H}, 6.07$. $\delta_{\mathrm{H}}\left(400 \mathrm{MHz}\right.$, acetone- $\left.\mathrm{d}_{6}\right) 0.97\left(3 \mathrm{H}, \mathrm{t},{ }^{3} J\right.$ 3, $\mathrm{CH}_{3}$ from $\left.n \mathrm{Bu}_{4} \mathrm{P}\right) 1.55\left(2 \mathrm{H}, \mathrm{m}, \mathrm{CH}_{2}\right.$ from $\left.n \mathrm{Bu}_{4} \mathrm{P}\right) 1.7\left(2 \mathrm{H}, \mathrm{m}, \mathrm{CH}_{2}\right.$ from $\left.n \mathrm{Bu}_{4} \mathrm{P}\right) 2.54(2 \mathrm{H}$, $\mathrm{m}, \mathrm{CH}_{2}$ from $\left.n \mathrm{Bu}_{4} \mathrm{P}\right) 3.5\left(6 \mathrm{H}, \mathrm{d},{ }^{3} J_{\mathrm{PH}} 4.9, \mathrm{P}^{\mathrm{B}}-\mathrm{OCH}_{3}\right) ; 3.77\left(9 \mathrm{H}, \mathrm{d},{ }^{3} J_{\mathrm{PH}} 4.9, \mathrm{P}^{\mathrm{A}}-\mathrm{OCH}_{3}\right) ; \delta_{\mathrm{P}}(400$ $\mathrm{MHz}$, acetone-d 6$) 31.06\left(\mathrm{~m},{ }^{1} J_{\mathrm{PB}-\mathrm{Pt}} 4962, \mathrm{P}^{\mathrm{B}}\right) 33.34\left(\mathrm{~m},{ }^{+} \mathrm{PBu}_{4}\right) 82.40\left(\mathrm{~m},{ }^{1} J_{\mathrm{PA}-\mathrm{Pt}} 6631, \mathrm{P}^{\mathrm{A}}\right)$.

\subsection{Catalytic reactions}

\subsubsection{Hydroamination of ethylene: typical procedure.}

The autoclave was charged with $\mathrm{PtBr}_{2}$ (46.2 mg, $0.13 \mathrm{mmol}$ ), $\mathrm{PPh}_{3}$ (2 equiv/Pt, $68.0 \mathrm{mg}, 0.26$ $\mathrm{mmol})$ and $n \mathrm{Bu}_{4} \mathrm{PBr}(10$ equiv/Pt, $441 \mathrm{mg}, 1.3 \mathrm{mmol}$ ), closed and submitted to several argonvacuum cycles. Distilled and degassed aniline $(4.1 \mathrm{~mL}, 45 \mathrm{mmol})$ was then syringed into the autoclave. The ethylene pipe was connected to the autoclave, purged, and the ethylene pressure was adjusted to 25 bars at RT ( $c a .100 \mathrm{mmol}$ ). The temperature was then raised to $150^{\circ} \mathrm{C}$. After $10 \mathrm{~h}$, the autoclave was allowed to cool to room temperature and slowly vented in a fume cupboard. The reaction mixture was poured into $120 \mathrm{~mL}$ of diethylether, stirred for $2 \mathrm{~h}$, and then filtered. The external standard ( $N, N$-di( $n$-butyl)aniline, $c a .0 .15 \mathrm{~g})$ was added to the collected ethereal phases and the solution analysed by GC and GC-MS.

\subsubsection{Hydroamination of 1-hexene: typical procedure.}

The autoclave was charged with $\mathrm{PtBr}_{2}\left(46.2 \mathrm{mg}, 0.13 \mathrm{mmol}\right.$ ), and $n \mathrm{Bu}_{4} \mathrm{PBr}$ (65 equiv/ $\mathrm{Pt}, 2.88$ $\mathrm{g}, 8.45 \mathrm{mmol}$ ), closed and submitted to several argon-vacuum cycles. Distilled and degassed aniline $(4.1 \mathrm{~mL}, 45 \mathrm{mmol})$ along with $\mathrm{P}(\mathrm{OMe})_{3}(1$ equiv/ $\mathrm{Pt}, 15.8 \mathrm{mg}, 0.13 \mathrm{mmol})$ and 1 hexene $(11.3 \mathrm{~mL}, 91 \mathrm{mmol})$ were then syringed sequentially into the autoclave. The temperature was then raised to $150^{\circ} \mathrm{C}$. After $10 \mathrm{~h}$, the autoclave was allowed to cool down to room temperature and slowly vented in a fume cupboard. The reaction mixture was then poured into $120 \mathrm{~mL}$ of diethylether, and stirred for $2 \mathrm{~h}$, and then filtered. The external standard ( $N, N$-di(n-butyl)aniline, $c a .0 .15 \mathrm{~g}$ ) was added to the collected ethereal phases and the solution analyzed by GC and GC-MS.

Taking into account the liquid nature of both substrates (aniline and 1-hexene), the hydroamination of 1-hexene by aniline could analogously be carried out using adapted Schlenk glass-ware as follows: A $35 \mathrm{~mL}$ Ace Pressure Tube was charged with $\mathrm{PtBr}_{2}$ (46.2 mg, $0.13 \mathrm{mmol})$ and $n \mathrm{Bu}_{4} \mathrm{PBr}(65$ equiv/Pt, $2.88 \mathrm{~g}, 8.45 \mathrm{mmol})$. Distilled and degassed aniline (4.1 mL, $45 \mathrm{mmol}$ ) along with $\mathrm{P}(\mathrm{OMe})_{3}$ (1 equiv/ $\left.\mathrm{Pt}, 15.8 \mathrm{mg}, 0.13 \mathrm{mmol}\right)$ and 1 -hexene $(11.3$ $\mathrm{mL}, 91 \mathrm{mmol})$ were then syringed sequentially into the Ace Pressure Tube. The temperature was then raised to $150^{\circ} \mathrm{C}$. After $10 \mathrm{~h}$, the reaction mixture was allowed to cool down to room temperature and poured into $120 \mathrm{~mL}$ of diethylether. The external standard $(N, N$-di $(n-$ butyl)aniline, $c a .0 .15 \mathrm{~g}$ ) was added to the collected ethereal phases and the solution analysed by GC and GC-MS.

\subsection{Study on the coordination chemistry of the $\mathrm{PtBr}_{2} / n \mathrm{Bu}_{4} \mathrm{PBr} / \mathrm{PR}_{3}$ catalytic system.}

Typical procedure: $\mathrm{PtBr}_{2}(0.13 \mathrm{mmol}, 46.2 \mathrm{mg}), n \mathrm{Bu}_{4} \mathrm{PBr}$ (65 equiv/Pt, $45 \mathrm{mmol}, 2.87 \mathrm{~g}$ ) and $\mathrm{PPh}_{3}$ (2 equiv/Pt, $0.26 \mathrm{mmol}, 68.0 \mathrm{mg}$ ) were weighted and placed in to a $25 \mathrm{~mL}$ round-bottom flask. $o$-Dichlorobenzene $(5 \mathrm{~mL})$ was added and a reflux condenser adapted to the system. The stirred reaction mixture was heated to $150^{\circ} \mathrm{C}$ in an oil bath. After $10 \mathrm{~h}$, the reaction mixture was allowed to cool down to room temperature, then the solvent was removed under reduced pressure and the crude analysed by ${ }^{31} \mathrm{P}$ NMR $\left(250 \mathrm{MHz}, \mathrm{CDCl}_{3}\right.$, see SI). When $\mathrm{PPh}_{3}$ and $\mathrm{P}(\mathrm{OPh})_{3}$ were used, crystals suitable for X-ray diffraction were grown while cooling down the reaction mixture to room temperature (see SI).

\subsection{X-ray Structure Determination.}

Single crystals of 7, 8 and 9 were mounted under inert perfluoropolyether at the tip of glass 
fibre and cooled in the cryostream of the Oxford-Diffraction XCALIBUR CCD diffractometer. Data were collected using the monochromatic MoK $\alpha$ radiation $(\lambda=0.71073)$. The structures were solved by direct methods (SIR97) [17] and refined by least-squares procedures on F2 using SHELXL-97 [18]. All H atoms attached to carbon were introduced in calculation in idealised positions and treated as riding models. The drawing of the molecules was realised with the help of ORTEP32 [19]. Crystal data and refinement parameters are shown in Table 3-5 from the SI.

Crystallographic data (excluding structure factors) have been deposited with the Cambridge Crystallographic Data Centre as supplementary publication no. CCDC 878731 - 878733. Copies of the data can be obtained free of charge on application to the Director, CCDC, 12 Union Road, Cambridge CB2 1EZ, UK (fax: (+44) 1223-336-033; e-mail: deposit@ccdc.cam.ac.uk). 


\section{RESULTS AND DISCUSSION}

\subsection{Hydroamination of ethylene by aniline in the presence of phosphorus ligands}

Taken the urgency to develop new catalytic systems for the intermolecular hydroamination of non-activated olefins and the consolidated reputation of phosphorus ligands to accomplish this type of task for a large range of catalytic reactions (see introduction), we were prompted to investigate the effect of several classical and simple phosphorus ligands in the intermolecular hydroamination of ethylene by aniline as model reaction (Scheme 4). Aiming to improve the already efficient stable low-loading $(0.3 \mathrm{~mol} \%)$ "one-pot" ready-to-use $\mathrm{PtBr}_{2} / n \mathrm{Bu}_{4} \mathrm{PBr}$ system recently discovered in our team [5b,5c], we carried some studies to identify a compatible class of ligand able to afford good catalytic activities and capable of playing the role of a potential chiral vector.

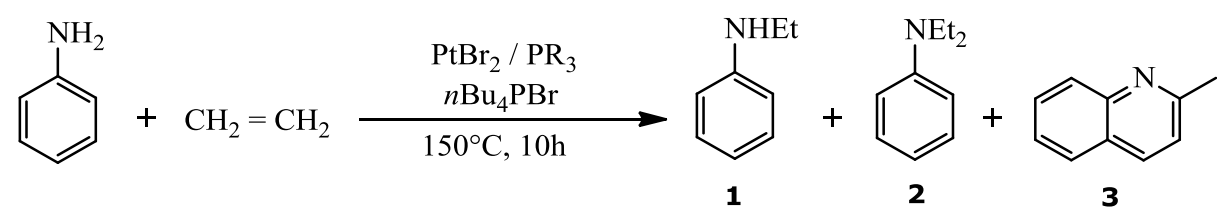

Scheme 4. Pt-catalysed intermolecular hydroamination of ethylene by aniline in the presence of $\mathrm{PR}_{3}$

In this work, we were led to consider the TON (mol of product formed by mol of catalyst) in order to evaluate the efficiency of the catalyst.

In a previous report, it was briefly pointed out that the catalytic efficiency for the hydroamination of ethylene (Scheme 4) could be dramatically affected by the presence of phosphorus ligands [20]. In order to confirm and generalise our observations, it was decided to investigate the influence of the $\mathrm{PR}_{3} / \mathrm{PtBr}_{2}$ ratio and the nature of the associated ligand for the hydroamination of ethylene with aniline. For this study, experiments were conducted without acid co-catalyst in order to better observe the role of the phosphorus additives. According to previous studies, the selected reaction time was $10 \mathrm{~h}$ and the chosen reaction temperature was $150^{\circ} \mathrm{C}$.

At first, it must be recalled that, in the absence of $\mathrm{PR}_{3}$ ligands, the $\mathrm{PtBr}_{2}$-based systems exhibit catalytic activity up to TON $=102$ (entry 1 , Table 1) for the formation of the hydroamination product 1 (Scheme 4).

The influence of the nature of the phosphorus ligands was studied using several types of phosphines containing alkyl, aryl, aryloxy or alkoxy substituents and the results are listed in Table 1.

Table 1. Effect of the amount and nature of the phosphorus ligands used on the $\mathrm{PtBr}_{2}-$ catalysed hydroamination of ethylene by aniline. ${ }^{\mathrm{a}}$

\begin{tabular}{lllll} 
Entry & Ligand (equiv/Pt) & TON 1 $^{\mathrm{b}}$ & $\mathrm{TON} \mathrm{2}^{\mathrm{b}}$ & $\mathrm{TON} \mathrm{3}^{\mathrm{b}}$ \\
\hline 1 & - & 102 & 5 & 15 \\
2 & $\mathrm{PPh}_{3}(1)$ & 18 & - & 23 \\
3 & $\mathrm{PPh}_{3}(2)$ & 11 & - & 19 \\
4 & $n \mathrm{Bu}_{3} \mathrm{P}(1)$ & 31 & - & 6 \\
5 & $n \mathrm{Bu}_{3} \mathrm{P}(2)$ & 5 & - & 4 \\
6 & $\mathrm{P}(\mathrm{OMe})_{3}(1)$ & 98 & 4 & 10 \\
7 & $\mathrm{P}(\mathrm{OMe})_{3}(2)$ & 112 & 6 & 8 \\
8 & $\mathrm{P}(\mathrm{OPh})_{3}(1)$ & 24 & - & - \\
9 & $\mathrm{P}(\mathrm{OPh})_{3}(2)$ & $<1$ & - & -
\end{tabular}

${ }^{a}$ Conditions: $\mathrm{PtBr}_{2}(46.1 \mathrm{mg}, 0.13 \mathrm{mmol}), \mathrm{PR}_{3}, n \mathrm{Bu}_{4} \mathrm{PBr}(0.4412 \mathrm{~g}, 1.30 \mathrm{mmol}), \mathrm{PhNH}_{2}$ (4.1 $\mathrm{mL}, 45.5 \mathrm{mmol}), \mathrm{C}_{2} \mathrm{H}_{4}(25 \mathrm{bar}, c a .100 \mathrm{mmol}), 150^{\circ} \mathrm{C}, 10 \mathrm{~h} .{ }^{\mathrm{b}} N$-ethylaniline (1), $N, N$ - 
diethylaniline (2), 2-methyl-quinoline (3).

These results showed that to the exception of $\mathrm{P}(\mathrm{OMe})_{3}$ (entries 6-7, Table 1), phosphorus ligands seem to be inhibitors. It seems that this effect is enhanced when using 2 equiv of ligand/Pt mainly due to a lower production of $\mathbf{1}$.

In the case of $\mathrm{PPh}_{3}$ (entries 2-3, Table 1) the observed catalytic performance is in contrast with our previous results on the $\mathrm{Rh}^{\mathrm{III}}$-catalysed reactions of aniline with ethylene [5g,5h], where aromatic phosphorus ligands such as $\mathrm{PPh}_{3}$ seemed to allow excellent catalytic activities. In the same way, aryloxy-substituted ligands (triarylphosphites) and trialkylphosphines allow the reaction but are inefficient co-catalysts (entries 4-5, 8-9).

Unexpectedly, catalytic activity is fully recovered upon the introduction of alkoxy groups as substituents on the phosphorus atoms. Indeed, results obtained with 2 equiv/ $\mathrm{Pt}$ of $\mathrm{P}(\mathrm{OMe})_{3}$ (entries 6-7, Table 1) showed that this ligand does afford higher selectivity (less production of 2 and 3 side-products) and catalytic activity for the formation of the desired product, $\mathrm{N}$ ethylaniline 1, than when the reaction is performed in the absence of ligand. Thus, the presence of alkoxy groups in the structure of the phosphorus ligands seems to be a key factor for achieving good catalytic activities.

According to results stated in Table 1, alkyl phosphites may represent the only type of phosphorus ligand without an inhibitor effect and thus suitable for the studied reaction.

\subsection{Hydroamination of higher $\alpha$-olefins in the presence of phosphorus ligands}

In order to potentially widen the scope of this catalytic process, we studied the addition of aniline to higher $\alpha$-olefins such as 1-hexene in the presence of a variety of phosphorus ligands.

The products resulting from these reactions are of great relevance in industry and the transformation of higher $\alpha$-olefins is itself an important scientific challenge [21,15d]. Literature on the intermolecular hydroamination of higher olefins by simple amines is very scarce and quite recent [2a,5c,15b,22-25]. Marks and co-workers [2a,22] studied the hydroamination of 1 -pentene with $n$-propylamine and reported to deal with a challenging reaction, the intermolecular hydroamination of non-activated alkenes, in comparison to intramolecular hydroamination, 350x faster, and alkyne hydroamination, 1400x faster. To the best of our knowledge, only four reports have appointed the use of phosphorus ligands for the intermolecular hydroamination of higher non-activated $\alpha$-olefins. First, He et al. worked on the addition of $\mathrm{TosNH}_{2}$ to 1 -octene with $5 \mathrm{~mol} \%$ of $\mathrm{Ph}_{3} \mathrm{PAuCl} / \mathrm{AgOTf}$ in toluene at $85^{\circ} \mathrm{C} \mathrm{[23]}$. Later on, Loh and co-workers studied the same reaction in the presence of $\operatorname{InBr}_{3}(20 \mathrm{~mol} \%)$ in toluene at $120^{\circ} \mathrm{C}$ [24]. Both groups obtained the desired Markovnikov hydroamination product along with another Markovnikov isomer resulting from the hydroamination of an internal alkene formed by isomerisation of the initial terminal double bond alkene. Next, Agbossou-Niedercorn and Michon (see introduction), used dppe for the hydroamination of 1hexene by $\mathrm{TosNH}_{2}$ [15b]. Using $\mathrm{AuClPR}_{3}\left(\mathrm{PR}_{3}=\mathrm{P}(t \mathrm{Bu})_{2} \mathrm{O}\right.$-biphenyl and 2-di-tertbutylphosphino-1,1'-binaphthyl) complexes Widenhoefer and co-workers successfully hydroaminated 1-alkenes with very low basicity amines [25].

As may be seen from literature, only group $11(\mathrm{Au}, \mathrm{Cu}, \mathrm{Ag})$ transition metals have been associated with phosphorus ligands to investigate the title reaction. Thus, the addition of aniline to 1-hexene (Scheme 5) was studied using Pt/P-based catalytic systems.

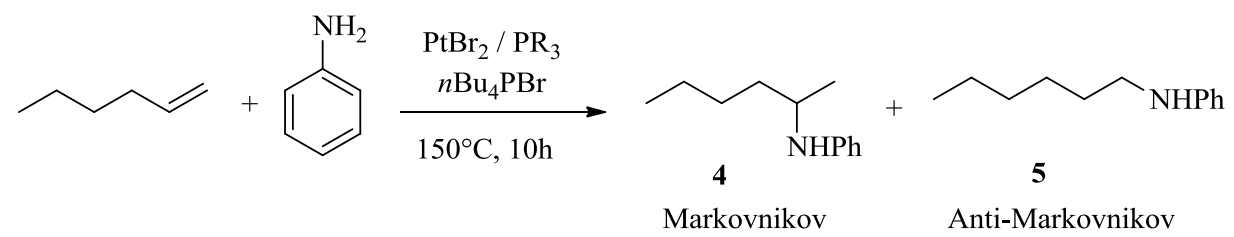


Scheme 5. Pt-catalysed intermolecular hydroamination of 1-hexene by aniline in the presence of $\mathrm{PR}_{3}$.

Catalytic results have revealed that, to the exception of alkyl phosphites $\left(\mathrm{P}(\mathrm{OEt})_{3}\right.$ and $\mathrm{P}(\mathrm{OMe})_{3}$, entries 7-10, Table 1 from SI), the catalytic activity of this reaction seems, once more, inhibited in the presence of phosphorus ligands. As in the case of ethylene, this is true for aromatic phosphines, alkyl phosphines and aromatic phosphites (see Table 1 from SI for further details), confirming our hypothesis on the need of a $\mathrm{P}-\mathrm{O}-\mathrm{C}$ bond in the structure of the ligand to obtain a good catalytic performance.

These results seem to confirm a strong coordination mode between the metal centre and the ligands, completely deactivating the catalytic system by blocking its active sites.

This is somehow confirmed by the results obtained (TON $=1.5)$ for the hydroamination of 1 hexene $\left(1.6 \mathrm{~mL}, 12.73 \mathrm{mmol}, 150^{\circ} \mathrm{C}, 144 \mathrm{~h}\right)$ by aniline $(4.1 \mathrm{~mL}, 45 \mathrm{mmol})$ in the presence of preformed cis- $\mathrm{PtBr}_{2}\left(\mathrm{PPh}_{3}\right)_{2}(0.114 \mathrm{~g}, 0.13 \mathrm{mmol})$ and $n \mathrm{Bu} 4 \mathrm{PBr}(6.62 \mathrm{~g}, 19.5 \mathrm{mmol})$.

On the basis of previous results on the platinum-catalysed hydroamination of alkenes [5c], the possible role of molecular iodine was also considered. The association of the reported inhibitor systems, $n \mathrm{Bu}_{4} \mathrm{PBr} / \mathrm{dppp}$ (dppp $=$ 1,2-bis(diphenylphosphino)propane) and $n \mathrm{Bu}_{4} \mathrm{PI} / \mathrm{PPh}_{3}$, with molecular iodine allows to recover the catalytic activity in the presence of $\mathrm{PtBr}_{2}$ (see Table 2 from SI for further details). These results may be understood as $\mathrm{I}_{2}$ being an antidote for the poisoning effect of aromatic phosphines by forming $\left[\mathrm{R}_{3} \mathrm{PX}\right]^{+} \mathrm{X}^{-}$salts $(\mathrm{Scheme}$ 6) as described in the literature [26].

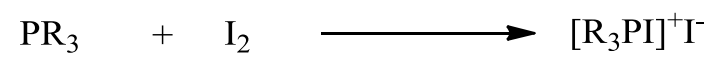

Scheme 6. Formation of $\left[\mathrm{R}_{3} \mathrm{PX}\right]^{+} \mathrm{X}^{-}$salts from $\mathrm{PR}_{3}$ and $\mathrm{I}_{2}$

To confirm this hypothesis, we have studied the ${ }^{31} \mathrm{P}$ NMR (under inert atmosphere) of the reaction mixture of a typical catalytic run in the presence of triphenylphosphine. Two signals were identified: the expected signal corresponding to the phosphonium salt, $n \mathrm{Bu}_{4} \mathrm{PI}$, at $\delta_{\mathrm{P}}=$ $33.1 \mathrm{ppm}$, along with another signal $\left(\delta_{\mathrm{P}}=26.9 \mathrm{ppm}\right.$, major product $)$ that could be attributed to iodotriphenylphosphonium iodide, $\left[\mathrm{R}_{3} \mathrm{PI}\right]^{+} \mathrm{I}^{-}$, by correlation with the ${ }^{31} \mathrm{P}$ NMR data obtained from the in situ NMR reaction (at room temperature in acetone- $\mathrm{d}_{6}$ ) between $\mathrm{PPh}_{3}$ and $\mathrm{I}_{2}$.

A more detailed discussion about the obtained catalytic results along with literature data for the hydroamination of 1-hexene in the presence of phosphorus ligands and/or $\mathrm{I}_{2}$ is available in the supporting information (SI).

It is premature to speculate about the exact role of these phosphorus-containing ligands and mechanistic studies are required to gain full insight into these phenomena. A full mechanistic study on the title reaction is out of the scope of this article and will be addressed in future publications. Although the NMR monitoring of the catalytic process could have provided some important insights on the active catalytic species and on possible intermediates of the catalytic cycle, this study could not be done due to technical difficulties (high temperature, $150{ }^{\circ} \mathrm{C}$, during $10 \mathrm{~h}$, and high pressure, $25 \mathrm{bar}$, in the case of ethylene as starting olefin). As a preliminary alternative we have tried to recover the catalyst at the end of the reaction in order to evaluate, by ${ }^{195} \mathrm{Pt} \mathrm{NMR}$, the absence/presence of phosphorus containing platinum complexes that could explain the observed catalytic results. Decomposition of the active platinum species to black $\mathrm{Pt}^{0}$ (black precipitate at the end of the catalytic process) did not allow us to observe any platinum containing species by the NMR technique.

\subsection{Hydroamination in the presence of Arbuzov-type phosphorus containing Pt- complexes}

On the basis of the good catalytic results obtained with the association of $\mathrm{PtBr}_{2}$ with $n \mathrm{Bu}_{4} \mathrm{PI}$ 
and alkylphosphites, our next efforts were aimed at investigating the particularly beneficial effect of this unique type of phosphorus ligands in the intermolecular Pt-catalysed hydroamination of ethylene by aniline.

For this study we addressed an important question concerning the fact that alkylphosphites allow high catalytic activities whereas alkyl- and arylphosphines, and even arylphosphites, behave as inhibitors.

Our first hypothesis was based on chemical structural differences between phosphorus promoters and inhibitors: alkylphosphites are the only ones to have O-alkyl substituents on the phosphorus atom. Thus we were prompted to consider an "in situ" transformation, under the catalytic conditions, of metal-coordinated alkylphosphites into somehow more active species according to a Michaelis-Arbuzov type reaction. As described by Odinets et al [27], the Michaelis-Arbuzov reaction allows the formation of a $\mathrm{P}=\mathrm{O}$ bond by reaction of an alkylphosphite with an alkylhalide (Scheme 7).

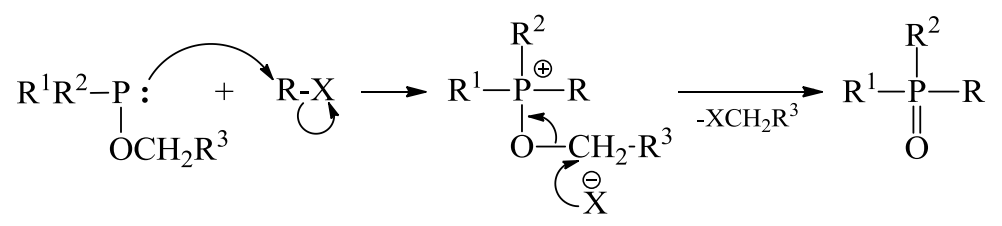

\section{Scheme 7. Michaelis-Arbuzov reaction}

Taking a look into literature data we could find several reports on a special type of MichaelisArbuzov reaction where, similarly, a metallic complex containing one or more halogen ligands allows the reaction (Scheme 8) [28]. Interestingly, authors report this reaction to take place at moderate to high temperatures when reaction times are prolonged, as in our case.

$\mathrm{P}(\mathrm{OR})_{3}+\mathrm{L}_{\mathrm{n}} \mathrm{M}-\mathrm{X} \longrightarrow \mathrm{L}_{\mathrm{n}} \mathrm{M}-\mathrm{P}(\mathrm{O})(\mathrm{OR})_{2}+\mathrm{RX}$

Scheme 8. Michaelis-Arbuzov reaction in metallic complexes

Roundhill and co-workers reported an interesting study on successive Michaelis-Arbuzov reactions on various alkoxy groups from the phosphorus ligand. They succeeded in the formation of transition metal complexes containing different type of phosphorus ligands in equilibrium, when several equivalents of alkylphosphite reacted with a chosen metallic complex (Scheme 9) [29].<smiles>[R]OP([R2])[PH]([R2])([X])[X]</smiles><smiles>CP(=O)(O)P(C)(C)(C)[Pb][CH][O+]P(C)(C)(C)C</smiles>

Scheme 9. Transition-metal Michaelis-Arbuzov reaction described by Roundhill and coworkers [29].

Taking into account the state of the art, and in order to confirm our hypothesis on the Michaelis-Arbuzov reaction to be responsible of the particular catalytic effect of alkylphosphites, further catalytic experiments were conducted in the presence of a preformed Pt-complex containing a Michaelis-Arbuzov type phosphorus ligand. Thus, the complex cis$\left[\mathrm{PtBr}_{2}\left(\mathrm{P}\left(\mathrm{OCH}_{3}\right)_{3}\right)\left(\mathrm{OP}\left(\mathrm{OCH}_{3}\right)_{2}\right)\right]\left(n \mathrm{Bu}_{4} \mathrm{P}\right)(6)(\mathrm{Scheme} 10)$ was synthesised (see experimental section) and used along with $n \mathrm{Bu}_{4} \mathrm{PBr}$ for the catalytic hydroamination of ethylene by aniline (Scheme 11). 


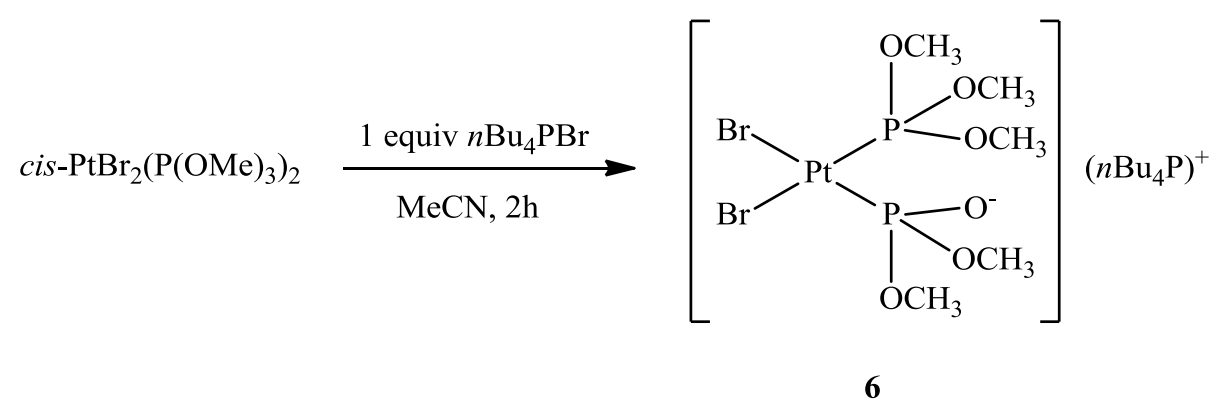

Scheme 10. Preparation of compound cis- $\left[\mathrm{PtBr}_{2}\left(\mathrm{P}\left(\mathrm{OCH}_{3}\right)_{3}\right)\left(\mathrm{OP}\left(\mathrm{OCH}_{3}\right)_{2}\right)\right](n \mathrm{Bu} 4 \mathrm{P})(6)$

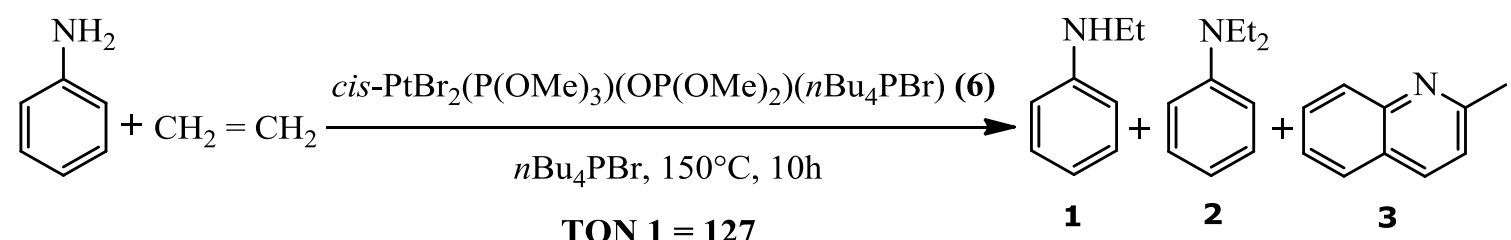

Scheme 11. Catalytic hydroamination of ethylene by aniline in the presence of compound (6)

Results in this area were particularly interesting. Indeed, TON up to 127 towards the production of $1(\mathrm{TON} 1=127$, TON2 $=5, \mathrm{TON} 3=4)$ were obtained using the association of cis- $\left[\mathrm{PtBr}_{2}\left(\mathrm{P}\left(\mathrm{OCH}_{3}\right)_{3}\right)\left(\mathrm{OP}\left(\mathrm{OCH}_{3}\right)_{2}\right)\right]\left(n \mathrm{Bu}_{4} \mathrm{P}\right) \quad$ (6) $(0.3 \mathrm{~mol} \%, 0.13 \mathrm{mmol}, 0.110 \mathrm{~g})$ with $n \mathrm{Bu}_{4} \mathrm{PBr}(10$ equiv/Pt, $0.4412 \mathrm{~g}, 1.30 \mathrm{mmol})$, a particularly efficient system for the hydroamination of ethylene $\left(25 \mathrm{bar}, \mathrm{ca} .100 \mathrm{mmol}, 150^{\circ} \mathrm{C}\right.$ and $\left.10 \mathrm{~h}\right)$ by aniline $(4.1 \mathrm{~mL}, 45.5$ mmol) and even more active and selective towards the formation of $\mathbf{1}$, under comparable conditions, than the platinum system $\mathrm{PtBr}_{2} / 10 n \mathrm{Bu} 4 \mathrm{PBr} / 2 \mathrm{P}(\mathrm{OMe})_{3}$ (entry 7, Table 1). It is important to note that no black $\mathrm{Pt}(0)$ has been observed at the end of the reaction when performing the catalytic tests in the presence of cis- $\left[\mathrm{PtBr}_{2}\left(\mathrm{P}\left(\mathrm{OCH}_{3}\right)_{3}\right)\left(\mathrm{OP}\left(\mathrm{OCH}_{3}\right)_{2}\right)\right]\left(n \mathrm{Bu}_{4} \mathrm{P}\right)$. This seems to point out an important feature of this system: a high stability of the catalytically active species even at high temperature and in a reductive media.

A mechanistic study on the Pt-catalysed hydroamination reaction in the presence of $\mathrm{P}$ containing ligands will be addressed in future works.

\subsection{Coordination Chemistry of the $\mathrm{PtBr}_{2} / n \mathrm{Bu}_{4} \mathrm{PBr} / \mathrm{PR}_{3}$ catalytic systems}

As stated above, one of the advantages of the catalytic strategy used in the present study was the possibility to add in a "one-pot" manner the components of the catalytic system. Nevertheless, in order to better understand the coordination abilities of the metal centre towards the added phosphine ligands, we decided to explore a few more experiments on the reactivity of $\mathrm{PtBr}_{2}$ with some of the phosphine and phosphites used for the hydroamination reaction. Surprisingly, literature data on this subject are still scarce [30].

For this purpose, $\mathrm{PtBr}_{2}$ was reacted with 1 and 2 equiv/Pt of three different phosphorus ligands $\left(\mathrm{PPh}_{3}, \mathrm{P}(\mathrm{OEt})_{3}\right.$ and $\left.\mathrm{P}(\mathrm{OPh})_{3}\right)$, in the presence of $n \mathrm{Bu}_{4} \mathrm{PBr}$.

Surprisingly, the reactivity of $\mathrm{PtBr}_{2}$ towards aromatic phosphines, aromatic phosphites and alkyl phosphites was found to be quite different under the same reaction conditions. 


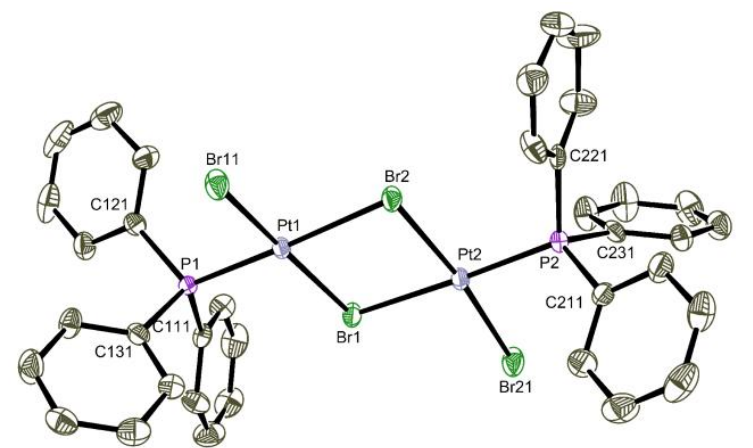

Figure 1. Molecular view of compound 7 trans- $\left[\mathrm{PtBr}_{2}\left(\mathrm{PPh}_{3}\right)\right]_{2}$ with the atom-labelling scheme.

As expected, the reaction of $\mathrm{PtBr}_{2}$ with 1 equiv/Pt of $\mathrm{PPh}_{3}$ gave a new binuclear complex trans-[ $\left.\mathrm{PtBr}_{2}\left(\mathrm{PPh}_{3}\right)_{2}\right]_{2} 7$ (Figure 1) while 2 equiv/Pt of $\mathrm{PPh}_{3}$ gave the already known mononuclear complex cis- $\mathrm{PtBr}_{2}\left(\mathrm{PPh}_{3}\right)_{2} 8$ (Figure 2).

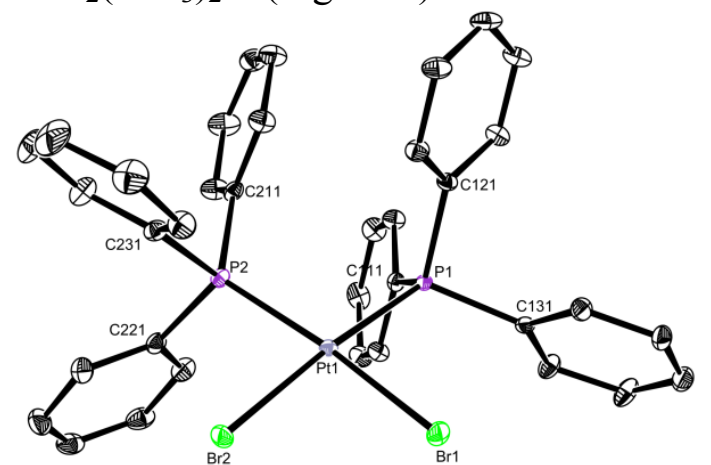

Figure 2. Molecular view of compound cis- $\mathrm{PtBr}_{2}\left(\mathrm{PPh}_{3}\right)_{2}, \mathbf{8}$, with the atom-labelling scheme.

Interestingly, the same reaction under the same conditions but using 1 or 2 equiv/ $\mathrm{Pt}$ of $\mathrm{P}(\mathrm{OPh})_{3}$ gave only the mononuclear complex cis- $\mathrm{PtBr}_{2}\left(\mathrm{P}(\mathrm{OPh})_{3}\right)_{2} 9$ (Figure 3) as stated by a very clean ${ }^{31} \mathrm{P}$ NMR spectra.

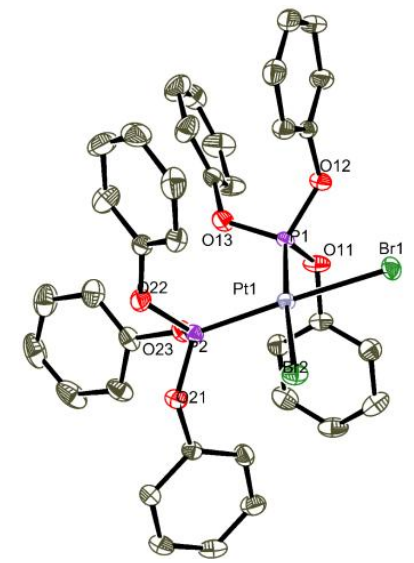

Figure 3. Molecular view of compound cis- $\mathrm{PtBr}_{2}\left(\mathrm{P}(\mathrm{OPh})_{3}\right)_{2}$, 9, with the atom-labelling scheme.

Concerning $\mathrm{P}(\mathrm{OEt})_{3}$ ligand, its coordination chemistry with $\mathrm{PtBr}_{2}$ seems less straight forward and we tentatively propose the formation of cis- $\mathrm{PtBr}_{2}\left(\mathrm{P}(\mathrm{OEt})_{3}\right)_{2}$ along with, as expected, platinum complexes containing several Arbuzov-type phosphorus ligand according to related literature data.

Single crystals suitable for X-ray diffraction were obtained for compounds 7-9 while cooling down the reaction mixture to room temperature (see experimental section and SI for further details). 
A more detailed discussion about the obtained results along with experimental, spectroscopic and crystallographic data for 7-9 complexes and related compounds is available in the supporting information (SI). 


\section{CONCLUSIONS}

An important effect of phosphorus co-catalysts on the intermolecular Pt-catalysed hydroamination of ethylene and 1-hexene by aniline has been evidenced. Indeed, although alkyl- and arylphosphines, as well as arylphosphites, inhibit the reaction, alkylphosphites showed to be a unique class of ligands suitable for the title reaction. We have investigated this particular effect of alkylphosphites and found that the association $\mathrm{PtBr}_{2}\left(\mathrm{P}(\mathrm{OMe})_{3}\right)\left(\mathrm{OP}(\mathrm{OMe})_{2}\right) / 10 n \mathrm{Bu}_{4} \mathrm{PBr}$ is a very efficient catalytic system allowing even higher TON than the $\mathrm{PtBr}_{2} / 10 n \mathrm{Bu}_{4} \mathrm{PBr} / 2 \mathrm{P}(\mathrm{OMe})_{3}$ catalyst studied in this work and the previously reported $\mathrm{PtBr}_{2} / 10 n \mathrm{Bu}_{4} \mathrm{PBr}$ system [5b].

These results give access to a new broad family of efficient Arbuzov-type ligands for homogeneous catalytic processes. Modulation of their structural properties could provide a large range of new Arbuzov-like phosphoranes. Even more important, these phosphorus containing co-catalysts may represent the first family of ligands suitable for the intermolecular Pt-catalysed hydroamination of ethylene and higher $\alpha$-olefins and thus become an important option when considering the enantioselective version of this reaction; an important scientific challenge (see introduction). Indeed, a new series of chiral catalysts could be considered combining, in the coordination sphere of a transition metal centre, different phosphonites $\mathrm{P}\left(\mathrm{OR}^{1}\right)_{2} \mathrm{R}^{2}$ and/or phosphinites $\mathrm{P}\left(\mathrm{OR}^{1}\right) \mathrm{R}^{2} \mathrm{R}^{3}$ bearing a chiral $\mathrm{R}^{2}$ and/or $\mathrm{R}^{3}$ group or, alternatively, 2 different $\mathrm{R}^{2}$ and $\mathrm{R}^{3}$ groups.

Furthermore, we have been able to evidence a preventing effect of $\mathrm{I}_{2}$ towards the poisoning effect of phosphines and arylphosphites on the studied reactions by the formation of $\left[\mathrm{R}_{3} \mathrm{PI}\right]^{+} \mathrm{I}^{-}$ type salts.

Investigations on the coordination chemistry of $\mathrm{PtBr}_{2}$ with $\mathrm{PPh}_{3}, \mathrm{P}(\mathrm{OPh})_{3}$ and $\mathrm{P}(\mathrm{OEt})_{3}$ have revealed an interesting behaviour when using phosphites (only monomers are formed) and provide a new X-ray structure for the dimer complex trans- $\left[\mathrm{PtBr}_{2}\left(\mathrm{PPh}_{3}\right)\right]_{2}$. 


\section{ACKNOWLEDGMENTS}

We are grateful to The Centre National de la Recherche Scientifique (CNRS, France) and the FSE (post-doctoral grant to SA) for funding. Dr. J.-J. Bonnet and Dr. D. Neibecker are acknowledged for academic support and Prof. F.-X. Felpin and Dr. F. Malbosc (Solvionic) for fruitful discussions. 


\section{SUPPORTING INFORMATION}

A detailed discussion about the obtained results on i) the hydroamination of 1-hexene in the presence of phosphorus ligands and/or $\mathrm{I}_{2}$ along with literature data, and ii) the coordination chemistry of the $\mathrm{PtBr}_{2} / n \mathrm{Bu}_{4} \mathrm{PBr} / \mathrm{PR}_{3}$ catalytic systems along with experimental, spectroscopic and crystallographic data for 7-9 complexes and related compounds, is available in the Supporting Information (SI). This material is available free of charge via the Internet. 


\section{REFERENCES}

[1] a) A. E. Schweizer, R. L. Fowlkes, J. H. Mc Clain, T. E. Whyte Jr, Kirk-Othmer Encyclopedia of Chemistry and Technology, Wiley, New York, 1978, vol. 2, pp. 272-283; b) H. B. Bathina, R. A. Reck, Kirk-Othmer Concise Encyclopedia of Chemistry and Technology, Wiley, New York, 1985, p 83; c) K. Weissermel, H.-J. Harpe, Industrial Organic Chemistry, second ed., VCH, Weinheim,. 1993; d) J.-J. Brunet, D. Neibecker in: A. Togni, H. Grützmacher (Eds.), Catalytic Heterofunctionalization, VCH, Weinheim, 2001, pp. 91-141.

[2] For selected reports on intramolecular hydroamination see: a) S. Hong, T. J. Marks, Acc. Chem. Res. 37 (2004) 673-686; b) J. Zhao, T. J. Marks, Organometallics 25 (2006) 47634772; c) D. V. Gribkov, K. C. Hultzsch, F. Hampel, J. Am. Chem. Soc. 128 (2006) 37483759 and references therein; d) H. F. Yuen, T. J. Marks, Organometallics 28 (2009) 24232440; e) J. Jenter, A. Luehl, P. W. Roesky, S. Blechert, J. Organomet. Chem. 696 (2010) 406-418; f) R. E. McKinney-Brooner, R. A. Widenhoefer, Chem. Eur. J. 17 (2011) 61706178; g) J. Deschamp, J. Collin, J. Hannedouche, E. Schulz, Eur. J. Org. Chem. 18 (2011) 3329-3338; h) Z. Liu, H. Yamamichi, S. T. Madrahimov, J. F. Hartwig, J. Am. Chem. Soc. 133 (2011) 2772-2782.

[3] For selected reports on hydroamination of alkynes and/or activated alkenes see: a) J.-J. Brunet, N. C. Chu, O. Diallo, E. Mothes, J. Mol. Catal. A: Chem. 198 (2003) 107-110; b) J.-J. Brunet, N. C. Chu, O. Diallo, S. Vincendeau, J. Mol. Catal. A: Chem. 240 (2005) 245-248; c) D. Karshtedt, T. A. Bell, T. D. Tilley, J. Am. Chem. Soc. 127 (2005) 1264012646; d) L. L. Anderson, J. Arnold, R. G. Bergman, J. Am. Chem. Soc. 127 (2005) 14542-14543; e) K. Komeyama, T. Morimoto, K. Takaki, Angew. Chem. Int. Ed. 45 (2006) 2938-2941; f) J. G. Taylor, N. Whittall, K. K. Hii, Org. Lett. 8 (2006) 3561; g) C. Brouwer and C. He, Angew. Chem. Int. Ed. 45 (2006) 1744-1747; h) L. Fadini, A. Togni, Helv. Chim. Acta. 90 (2007) 411-424; i) J. Zhou, J. F. Hartwig, J. Am. Chem. Soc. 130 (2008) 12220-12221; j) J. L. McBee, A. T. Bell, T. D. Tilley, J. Am. Chem. Soc. 130 (2008) 16562-16571; k) J. Cho, T. K. Hollis, R. H. Theodore, J. V. Edward, Chem. Commun. (2008) 5001-5003; 1) M. Biyikal, M. Porta, P. W. Roesky, S. Blechert, Adv. Synth. Catal. 352 (2010) 1870-1875; m) D. Jaspers, S. Doye, Synlett. 10 (2011) 14441448.

[4] a) V. Khedkar, A. Tillack, C. Benisch, J.-P. Melder, M. Beller, J. Mol. Catal. A: Chem. 241 (2005) 175-183; b) C. S. Yi, S. Y. Yun, Org. Lett. 7 (2005) 2181-2183.

[5] a) S. Anguille, J.-J. Brunet, N. C. Chu, O. Diallo, C. Pages, S. Vincendeau, Organometallics 25 (2006) 2943-2948; b) J.-J. Brunet, N. C. Chu, M. Rodriguez-Zubiri, Eur. J. Inorg. Chem. 30 (2007) 4711-4722; c) M. Rodriguez-Zubiri, S. Anguille, J.-J. Brunet, J. Mol. Catal. A: Chem. 271 (2007) 145-151; d) P. A. Dub, M. Rodriguez-Zubiri, J. C. Daran, J.-J. Brunet, R. Poli, Organometallics 28 (2009) 4764-4777; e) P. A. Dub, M. Rodriguez-Zubiri, C. Baudequin, R. Poli, Green Chem. 12 (2010) 1392; f) G. Aullon, K. Gomez, G. Gonzalez, S. Jansat, M. Martinez, R. Poli, M. Rodriguez-Zubiri, Inorg. Chem. 50 (2011) 5628-5636; g) C. Baudequin, J.-J. Brunet, M. Rodriguez-Zubiri, Organometallics 26 (2007) 5264-5266; h) M. Rodriguez-Zubiri, C. Baudequin, A. Béthegnies, J.-J. Brunet, ChemPlusChem 77 (2012) 445-454.

[6] a) A. B. Salah, C. Offenstein, D. Zargarian, Organometallics 30 (2011) 5352-5364; b) A. Flores-Figueroa, T. Pape, K.-O. Feldmann, F. E. Hahn, Chem. Commun. 46 (2010) 324326; c) L. Fadini, A. Togni, Tetrahedron: Asymmetry 19 (2008) 2555-2562; d) R. Corberan, S. Marrot, N. Dellus, N. Merceron-Saffon, T. Kato, E. Peris, A. Baceiredo, Organometallics 28 (2009) 326-330; e) J.-C. Caille, K. K. M. Hii, WO 2008059051 (2008); f) A. Behr, G. Henze, L. Johnen, S. Reyer, J. Mol. Catal. A: Chem. 287 (2008) 95101; g) E. Smolensky, M. Kapon, M. S. Eisen, Organometallics 26 (2007) 4510-4527; h) 
R. S. Jensen, K. Umeda, M. Okazaki, F. Ozawa, M. Yoshifuji, J. Organomet. Chem. 692 (2007) 286-294; i) J. Vcelak, J. Cermak, M. Czakoova, J. Storch, J. Mol. Catal. A: Chem. 259 (2006) 41-45; j) K. K. Hii, WO 2006103453 (2006); k) M. Shi, L.-P. Liu, J. Tang, Org. Lett. 8 (2006) 4043-4046; 1) L. Fadini, A. Togni, Chimia 58 (2004) 208-211; m) L. Fadini, A. Togni, Chem. Commun. (2003) 30-31; n) M. Kawatsura, J. F. Hartwig, Organometallics 20 (2001) 1960-1964.

[7] a) A. Pabis, R. Kaminski, G. Ciepielowski, S. Jankowski, P. Paneth, J. Org. Chem. 76 (2011) 8033-8035; b) X. Giner, C. Najera, Org. Lett. 10 (2008) 2919-2922; c) A. M. Johns, M. Utsunomiya, C. D. Incarvito, J. F. Hartwig, J. Am. Chem. Soc. 128 (2006) 1828-1839; d) J. Takaya, J. F. Hartwig, J. Am. Chem. Soc. 127 (2005) 5756-5757; e) L. K. Vo, D. A. Singleton, Org. Lett. 6 (2004) 2469-2472; f) M. Beller, H. Trauthwein, M. Eichberger, C. Breindl, J. Herwig, T. E. Muller, O. R. Thiel, Chem. Eur. J. 5 (1999) 1306-1319.

[8] a) D. Vasen, A. Salzer, F. Gerhards, H.-J. Gais, R. Stuermer, N. H. Bieler, A. Togni, Organometallics 19 (2000) 539-546; b) R. Dorta, P. Egli, F. Zuercher, A. Togni, J. Am. Chem. Soc. 119 (1997) 10857-10858; c) J.-J. Brunet, G. Commenges, D. Neibecker, L. Rosenberg, J. Organomet. Chem. 522 (1996) 117-122.

[9] a) R. A. Sanguramath, T. N. Hooper, C. P. Butts, M. Green, J. E. McGrady, C. A. Russell, Angew. Chem. Int. Ed. 50 (2011) 7592-7595, S7592/1-S7592/16; b) A. Behr, L. Johnen, A. J. Vorholt, ChemCatChem 2 (2010) 1271-1277; c) A. Behr, L. Johnen, N. Rentmeister, Adv. Synth. Catal. 352 (2010) 2062-2072; d) R. Takita, Y. Takada, R. S. Jensen, M. Okazaki, F. Ozawa, Organometallics 27 (2008) 6279-6285; e) E. A. Petrushkina, V. N. Kalinin, G. B. Ivanova, V. A. Kheinman, Russ. J. Gen. Chem. 76 (2006) 1953-1957; f) T. Minami, H. Okamoto, S. Ikeda, R. Tanaka, F. Ozawa, M. Yoshifuji, Angew. Chem. Int. Ed. 40 (2001) 4501-4503.

[10] a) Z. J. Wang, D. Benitez, E. Tkatchouk, W. A. Goddard, F. D. Toste, J. Am. Chem. Soc. 132 (2010) 13064-13071; b) N. Nishina, Y. Yamamoto, Synlett (2007) 1767-1770; c) H. M. Wisniewska, E. R. Jarvo, Chem. Sci. 2 (2011) 807-810.

[11] a) N. T. Patil, V. Singh, Chem. Commun. 47 (2011) 11116-11118; b) A. Leyva-Perez, J. R. Cabrero-Antonino, A. Cantin, A. Corma, J. Org. Chem. 75 (2010) 7769-7780; c) A. Leyva, A. Corma, Adv. Synth. Catal. 351 (2009) 2876-2886; d) N. Pasha, N. S. Babu, K. T. Venkateswara Rao, P. S. S. Prasad, N. Lingaiah, Tetrahedron Lett. 50 (2009) 239-242; e) A. R. Shaffer, J. A. R. Schmidt, Organometallics 27 (2008) 1259-1266; f) Y. Fukumoto, H. Asai, M. Shimizu, N. Chatani, J. Am. Chem. Soc. 129 (2007) 13792-13793; g) E. Mizushima, N. Chatani, F. Kakiuchi, J. Organomet. Chem. 691 (2006) 5739-5745; h) M. L. Buil, M. A. Esteruelas, A. M. Lopez, A. C. Mateo, Organometallics 25 (2006) 40794089.

[12] For reports on intramolecular hydroamination of aminoalkenes see: a) N. K. Hangaly, A. R. Petrov, K. A. Rufanov, K. Harms, M. Elfferding, J. Sundermeyer, Organometallics 30 (2011) 4544-4554; b) T. O. Nguyen, B. Y.-W. Man, R. Hodgson, B. A. Messerle, Aust. J. Chem. 64 (2011) 741-746; c) H. Li, F.-J. Song, R. A. Widenhoefer, Adv. Synth. Catal. 353 (2011) 955-962; d) C. B. Lavery, M. J. Ferguson, M. Stradiotto, Organometallics 29 (2010) 6125-6128; e) L. D. Julian, J. F. Hartwig, J. Am. Chem. Soc. 132 (2010) 1381313822; f) K. D. Hesp, R. McDonald, M. Stradiotto, Can. J. Chem. 88 (2010) 700-708; g) J. D. Neukom, N. S. Perch, J. P. Wolfe, J. Am. Chem. Soc. 132 (2010) 6276-6277; h) G. Zi, F. Zhang, L. Xiang, Y. Chen, W. Fang, H. Song, Dalton Trans. 39 (2010) 4048-4061; i) X. Shen, S. L. Buchwald, Angew. Chem. Int. Ed. 49 (2010) 564-567, S564/1-S564/81; j) K. D. Hesp, S. Tobisch, M. Stradiotto, J. Am. Chem. Soc. 132 (2010) 413-426; k) A. V. Pawlikowski, A. Ellern, A. D. Sadow, Inorg. Chem. 48 (2009) 8020-8029; 1) C. Metallinos, J. Zaifman, L. Van Belle, L. Dodge, M. Pilkington, Organometallics 28 (2009) 4534-4543; m) A. Takemiya, Z. Liu, J. F. Hartwig, US Pat., 0156824 (2009); n) G. Zi, X. 
Liu, L. Xiang, H. Song, Organometallics 28 (2009) 1127-1137; o) L. Ackermann, A. Althammer, Synlett. (2008) 995-998; p) C. F. Bender, W. B. Hudson, R. A. Widenhoefer, Organometallics 27 (2008) 2356-2358; q) Z. Liu, J. F. Hartwig, J. Am. Chem. Soc. 130 (2008) 1570-1571; r) X. Yu, T. J. Marks, Organometallics 26 (2007) 365-376; s) D. A. Watson, M. Chiu, R. G. Bergman, Organometallics 25 (2006) 4731-4733; t) B. Revel, L. Delevoye, G. Tricot, M. Rastaetter, M. Kuzdrowska, P. W. Roesky, R. M. Gauvin, Eur. J. Inorg. Chem. 9 (2011) 1366-1369.

[13] For reports on intramolecular hydroamination of aminoalkynes see: a) H. Ito, T. Harada, H. Ohmiya, M. Sawamura, Beilstein J. Org. Chem. 7 (2011) 951-959, No. 106; b) S. R. Beeren, S. L. Dabb, G. Edwards, M. K. Smith, A. C. Willis, B. A. Messerle, New J. Chem. 34 (2010) 1200-1208; c) C. Wang, Z.-Y. Han, H.-W. Luo, L.-Z. Gong, Org. Lett. 12 (2010) 2266-2269; d) Z.-Y. Han, H. Xiao, X.-H. Chen, L.-Z. Gong, J. Am. Chem. Soc. 131 (2009) 9182-9183; e) L. D. Field, B. A. Messerle, K. Q. Vuong, P. Turner, Dalton Trans. (2009) 3599-3614; f) S. L. Dabb, J. H. H. Ho, R. Hodgson, B. A. Messerle, J. Wagler, Dalton Trans. (2009) 634-642; g) S. R. Beeren, S. L. Dabb, B. A. Messerle, J. Organomet. Chem. 694 (2009) 309-312; h) M. Narsireddy, Y. Yamamoto, J. Org. Chem. 73 (2008) 9698-9709; i) M. Rastaetter, A. Zulys, P. W. Roesky, Chem. Eur. J. 13 (2007) 3606-3616; j) L. D. Field, B. A. Messerle, K. Q. Vuong, P. Turner, T. Failes, Organometallics 26 (2007) 2058-2069; k) M. Rastaetter, A. Zulys, P. W. Roesky, Chem. Commun. (2006) 874876; 1) D. A. Krogstad, J. Cho, A. J. DeBoer, J. A. Klitzke, W. R. Sanow, H. A. Williams, J. A. Halfen, Inorg. Chim. Acta 359 (2006) 136-148; m) D. A. Krogstad, A. J. DeBoer, W. J. Ortmeier, J. W. Rudolf, J. A. Halfen, Inorg. Chem. Commun. 8 (2005) 1141-1144; n) T. K. Panda, A. Zulys, M. T. Gamer, P. W. Roesky, J. Organomet. Chem. 690 (2005) 50785089; o) L. D. Field, B. A. Messerle, K. Q. Vuong, P. Turner, Organometallics 24 (2005) 4241-4250; p) G. B. Bajracharya, Z. Huo, Y. Yamamoto, J. Org. Chem. 70 (2005) 48834886; q) T. K. Panda, A. Zulys, M. T. Gamer, P. W. Roesky, Organometallics 24 (2005) 2197-2202; r) D. A. Krogstad, S. B. Owens, J. A. Halfen, V. G. Young, Inorg. Chem. Commun. 8 (2005) 65-69; s) A. Zulys, T. K. Panda, M. T. Gamer, P. W. Roesky, Chem. Commun. (2004) 2584-2585; t) S. Burling, L. D. Field, B. A. Messerle, P. Turner, Organometallics 23 (2004) 1714-1721; u) L. M. Lutete, I. Kadota, Y. Yamamoto, J. Am. Chem. Soc. 126 (2004) 1622-1623; v) T. E. Muller, M. Grosche, E. Herdtweck, A.-K. Pleier, E. Walter, Y.-K. Yan, Organometallics 19 (2000) 170-183; w) T. E. Muller, A.-K. Pleier, Dalton Trans. (1999) 583-588.

[14] For reports on intramolecular hydroamination of aminoallenes see: a) A. S. K. Hashmi, A. M. Schuster, S. Litters, F. Rominger, M. Pernpointner, Chem. Eur. J. 17 (2011) 56615667, S5661/1-S5661/16; b) H. Li, S. D. Lee, R. A. Widenhoefer, J. Organomet. Chem. 696 (2010) 316-320; c) C. Bartolome, D. Garcia-Cuadrado, Z. Ramiro, P. Espinet, Organometallics 29 (2010) 3589-3592; d) K. Aikawa, M. Kojima, K. Mikami, Angew. Chem. Int. Ed. 48 (2009) 6073-6077, S6073/1-S6073/47; e) Z. Zhang, C. F. Bender, R. A. Widenhoefer, Org. Lett. 9 (2007) 2887-2889; f) R. L. LaLonde, B. D. Sherry, E. J. Kang, F. D. Toste, J. Am. Chem. Soc. 129 (2007) 2452-2453; g) J.-H. Kim, S.-W. Park, S.-R. Park, S.-Y. Lee, E.-J. Kang, Chem. Asian J. 6 (2011) 1982-1986.

[15] a) H. Li, S. du Lee, R. A. Widenhoefer, J. Organomet. Chem. 696 (2010) 316-320; b) C. Michon, F. Medina, F. Capet, P. Roussel, F. Agbossou-Niedercorn, Adv. Synth. Catal. 352 (2010) 3293-3305; c) H. Schaffrath, W. Keim, J. Mol. Cat. A: Chem. 163 (2001) 9-14; d) S. E. Diamond, A. Szalkiewicz, F. Mares, J. Am. Chem. Soc. 101:2 (1979) 490-491 and Fund. Res. Homogeneous Catal. 3 (1979) 345-358.

[16] a) M. J. Church and M. J. Mays, J. Inorg. Nucl. Chem. 33 (1971) 253-257; b) L. Rigamonti, A. Forni, M. Manassero, C. Manassero, A. Pasini, Inorg. Chem. 49 (2010) 123 135. 
[17] A. Altomare, M. C. Burla, M. Camalli, G. L. Cascarano, C. Giacovazzo, A. Guagliardi, A. G. G. Moliterni, G. Polidori, R. Spagn, SIR97 a program for automatic solution of crystal structures by direct methods, J. Appl. Cryst. 32 (1999) 115.

[18] G. M. Sheldrick, SHELXL97. Program for crystal structure refinement. University of Göttingen, Germany, 1997.

[19] L. Farrugia, J. ORTEP3 for Windows, J. Appl. Cryst. 30 (1997) 565.

[20] J.-J. Brunet, M. Cadena, N. C. Chu, O. Diallo, K. Jacob, E. Mothes, Organometallics 23 (2004) 1264.

[21] a) D. R. Coulson, Tetrahedron Lett. 12 (1971) 429-430; b) G. Pez, J. E. Galles, Pure Appl. Chem. 57 (1985) 1917-1926; c) G. Pez (Allied Chemical Corp.), US Pat., 4302603 (1981).

[22] a) Y. Li, T. J. Marks, Organometallics 15 (1996) 3770-3772; b) J. S. Ryu, G. Y. Li, T. J. Marks, J. Am. Chem. Soc. 125 (2003) 12584-12605.

[23] a) J. Zhang, C. G. Yang, C. He, J. Am. Chem. Soc. 128 (2006) 1798-1799.

[24] a) J. M. Huang, C. M. Wong, F. X. Xub, T. P. Loh, Tetrahedron Lett. 48 (2007) 33753377; b) P. Yin, T. P. Loh, Org. Lett. 11 (2009) 3791-3793.

[25] Z. Zhang, S. Du Lee, R. A. Widenhoefer, J. Am. Chem. Soc. 131 (2009) 5372-5373.

[26] a) D. Vlascici, E. Fagadar-Cosma, O. Spiridon-Bizerea, A. Pascariu, A. Chiriac, Rev. Chim. 56 (2005) 947; b) W. I. Cross, S. M. Godfrey, C. A. McAuliffe, R. G. Pritchard, J. M. Sheffield, G. M. Thompson, Dalton Trans. 16 (1999) 2795, and references therein; c) N. Bricklebank, S. M. Godfrey, A. G. Mackie, C. A. McAuliffe, R. G. Pritchard, P. J. Kobryn, Dalton Trans. (1993) 101-103; d) K. B. Dillon, J. Lincoln, Polyhedron 8 (1989) 1445; e) F. A. Cotton, P. A. Kibala, J. Am. Chem. Soc. 109 (1987) 3308; f) A. D. Beveridge, G. S. Harris, F. Inglis, J. Chem. Soc. A. 5 (1966) 520.

[27] E. V. Matveeva, I. L. Odinets, V. A. Kozlov, A. S. Shaplov, T. A. Mastryukova, Tetrahedron Lett. 47 (2006) 7645.

[28] See for example: a) S. J. Landon, T. B. Brill in J. Am. Chem. Soc. 104 (1982) 6571; Inorg. Chem. 23 (1984) 4177; Inorg. Chem. 23 (1984) 1266; Chem. Rev. 84 (1984) 577; b) D. E. Berry, K. A. Beveridge, J. Browning, G. W. Bushnell, K. R. Dixon in Can. J. Chem. 64 (1986) 1903-1911; Can. J. Chem. 63 (1985) 2949.

[29] C. King, D. M. Roundhill, Inorg. Chem. 25 (1986) 2271.

[30] a) B. Z. Maneni, H. Kazmi, A. Najafi, Helv. Chim. Acta 94 (2011) 1618; b) P. G. Waddell, A. M. Z. Slawin, J. D. Woollins, Dalton Trans. 39 (2010) 8620-8625; c) N. Ahmad, E. W. Ainscough, T. A. James, S. D. Robinson, Dalton Trans. (1973) 1148-1150; d) C. J. Cobley, P. G. Pringle, Inorg. Chim. Acta. 265 (1997) 107-115; e) Q.-B. Bao, T. B. Brill, Inorg. Chem. 26 (1987) 3447-3452; f) G. Albertin, S. Antoniutti, C. Busato, J. Castro, S. Garcia-Fontan, Dalton Trans. (2005) 2641-2649. 